\title{
Understanding the Text Content: Applying Asking - Question Technique in English Text for Mechanical Engineering Students
}

\section{Norita Prasetya Wardhani Institut Teknologi Adhi Tama Surabaya Qnoritanonoy@itats.ac.id \\ Muhammad Mujtaba Mitra \\ Zuana \\ Institut Pesantren KH. Abdul Chalim \\ Q mujtaba.mitrazuana@gmail.com}

\section{Keywords: \\ Asking \\ Question technique \\ Reading skill \\ Questions Mark}

Article Information:

Submitted: April 19, 2020

Accepted: April 20, 2020

Approved: May 18, 2020

\section{Abstract}

\begin{abstract}
Purpose - The study aims to observe the students 'skills in reading text with the instrument asking and writing the summary results read the text.
\end{abstract}

Design/methodology/approach - To explain the process and the result of students' writing wrote everything they saw in the class in field notes. Natural design and the phenomenon (descriptive qualitative) were also noted in the field note helping to analyze the data easily. The participants of this study were from mechanical engineering students, 53 students.

Findings - The result showed many students could answer the question given and write a summary of the text having been read.

Originality/value - Although this research is conducted at the university, the teachers, tutors, and parents to familiarize students or children with questions from the beginning six questions using WH-question mark. This is to train you to ask critically later when you become older. Because actually, the basic question with the WH-question mark is, directing students to take philosophical views.

Paper type - Research paper

\section{Introduction}

Today, most of the students use English as their textbooks or references for their study. Many of the engineering students felt it difficult to understand the content of the textbooks because they had lacked the motivation to understand English passages. Actually, the students on this campus realize if reading will add their knowledge but they feel English is difficult due to lack of vocabulary. Reading belongs to a complex activity involving either perception or thought, relating two processes: word recognition and comprehension (Sulaiman and Harpiansi 2018). To solve the problem, the students need more reading because reading is a key to improve their English understanding (Mikulecky and Jeffries 2005). It is suggested that the lecturer also gave the materials from fun media to make the students relax, such as 
magazines, newspapers, etc. relating to their major or materials. Many kinds of interesting reading materials might help readers to build their language competence. Therefore, readers require to obtain reading materials which can improve their interest. When the students have no interest to read a certain kind of reading material, they feel bored. It leads to a problem for the lecturer about how to apply the appropriate reading method to make the students interested in reading because the students' active participation in the class is an important aspect to enhance the language competencies of students (Muslimah 2018).

Reading involves by Barret a series of cognitive reading strategies to effectively locate, comprehend, synthesize, and communicate information (Lopatovska and Sessions 2016), and by van Dijk and Kintsch reading is the process of making meaning from text. The goal, therefore, is to gain an overall understanding of what is described in the text rather than to obtain meaning from isolated words or sentences (Woolley 2011). It should be noted that reading attitudes tend to be influenced by six aspects, namely "Entertaining and Important, "Lack of Interest, "Digital Reading Comfort, "Utilitarian Purposes, " "Difficult Access to Reading Materials" and "Mandatory Aspects" (Rabaud, Mamode Khan, and Rampat 2018). Furthermore combining quiet reading time with improved, higher-order journals and assessments can improve student motivation to read (Wineland 2016).

Brown stated that "implementing an appropriate teaching approach and suitable supplementary activities could be used successfully as base content for an integrated-skill". A simple technique is appropriate given to the students having a lack of motivation in English. But the technique must be interesting to improve students' reading habits. Students' discussion of what they read is a helpful strategy to increase their comprehension (Brown 2000). Using the Asking-Question technique would be appropriate to apply for mechanical engineering students. The students do not work alone if the lecturer applies this technique. The students work in pairs to finish their task. The Asking-question technique is used to explore the cause or effect of the engagement between the content and the question given. This technique asks the students to understand the content of the passage given by answering the question given by their friend. After answering the questions, the students must write a summary of the passage based on the text. Thus, this paper will describe students' understanding of writing and the passages from their summary. 


\section{Methodology}

The researchers used descriptive qualitative to explain the result of this study. They explained the process and the result of students' writing. They wrote everything they saw in the class in field notes. Natural design and the phenomenon were also noted in the field note Page | 47 helping them analyze the data easily. The data were taken during the English 1 class applying this asking question technique. They wrote down every phenomenon in the class during this technique was applied. The participants of this study were from mechanical engineering students, 53 students. On this campus, mechanical engineering students have a lack of motivation in learning English and many of them did not care about this subject because English is only a general subject. So, many of the students did not aware of this lesson.

The lecturer prepared two different passages that must be done by the students in this technique. Before the lecturer gave the passages, the lecturer taught few materials related to the materials, such as tenses, how to write sentences well, etc. It would make the students easier to write the questions and summaries. After the students do their task, the researchers would take a few random samples, which means, the researchers took random students writing who have advance-level, intermediate-level, and novice-level. The samples of the data were the students' writing. The students would write a few questions, answer the questions, and summarize. This study would examine content suitability and word order. We would check the grammatical, word order, capital letter, and conjunctions in students' writing. From this data, we could analyze the success of this technique and the way that influence the success of this technique.

\section{State of The Arts and Distinguish}

Asking-question technique means finding information from the passages having been read, using the WH-questions mark, and answering those questions based on the passages given. To make sure whether the readers have understood the passages or not, they must write a summary of the text based on what they accomplish before they write a summary of the text. Toyoda said that the asking-question technique is used to explore the cause or effects of the relationship of an appropriate problem. Giving questions is crucial for the students to engage the students with the content of the text which encourages the students and increases their understanding of the passage. Finding the main points will make the students easier to create questions. Then, they must write a summary based on the questions and answers which will 
make them understand the passage better. Besides, the students can try to write sentences well.

Leech in his research said that by giving questions, someone can collect information that you want and provide it in the respondent's own language and framework. Leech also added that if you take the time to ask these kinds of questions, you get a surprising answer and learn something new. He explained that there are several types of question which can give to the respondents. When respondents answer the questions, we know if they understood the questions or not (Leech 2002).

Another study have been done in 2011 by Wardhani which was explaining that asking question techniques was effective to be applied in junior high school students. Giving interesting passages from the magazine could help the students to understand the content of the text. Giving simple questions from the text and writing a summary of the text helped them understand the materials (Wardhani 2012).

\section{Findings and Discussion}

The researchers would explain what has been written in their field notes to know the process and the phenomenon that happened in the class. From the observation, researchers found that many mechanical engineering students felt difficult to understand the content of the passages. Their habit to read was very low, moreover reading English passages. It was one of the reasons for their difficulty in understanding the passages. Words orders also became a scourge for the students. The students only had few vocabularies, so they always found the vocabulary in an online dictionary to know the meaning. The students really needed teacher' roles to help them face their problems. Asking-question techniques could help mechanical engineering students understand the passages and this technique helped the students arrange and manage the sentences well. This technique asked the students to be responsible for their writing and others. They must have a big effort to make other students understand their writing.

In this research, we conducted twice because the students were still confused to write the sentences well. In the first activity, the lecturer didn't explain to write sentences well to the students but it was different when the researchers started the second one. The lecture taught the students how to write the sentence well orally and written. The lecturer explained the way to write well and gave the motivation to be confident to use English. In the first activity, the 
lecturer asked the students to read the passage in their textbook and asked the question relating to the text. The students must answer the question directly. As a result, all of the students could not answer the questions given. Because of this reason, the students must write questions and answer the questions in writing.

The data were the observation of the situation in natural design and the phenomenon while teaching the learning process using the asking-question technique in the class. The data were written in field notes to remind the researchers to explain the situation and phenomenon. The subject of this research was mechanical engineering students and their writings were used as the sample. The researchers took several random samples taken from advanced-level, intermediate-level, and novice-level students.

The students were divided into two groups; group A and group B. The text received by group A was different from group B. But their tasks were the same. Each student from group $A$ and $\mathrm{B}$ wrote six questions using the $\mathrm{WH}$-questions mark based on the text given. Each student would write different questions because they had their own understanding. The students had 35 minutes to write six questions. After each student wrote their questions, the questions and text from students in group $A$ were given to students in group $B$, and questions and text from group B were given to students in group $A$. They had to answer the questions based on the text exchanged. The students not only answered the question but also wrote the summary of the text exchange. Their time was 50 minutes.

Many students did not understand the content of the text. One of the pieces of evidence was many students had not understood the meaning of the questions given. There are examples of several confusing questions.

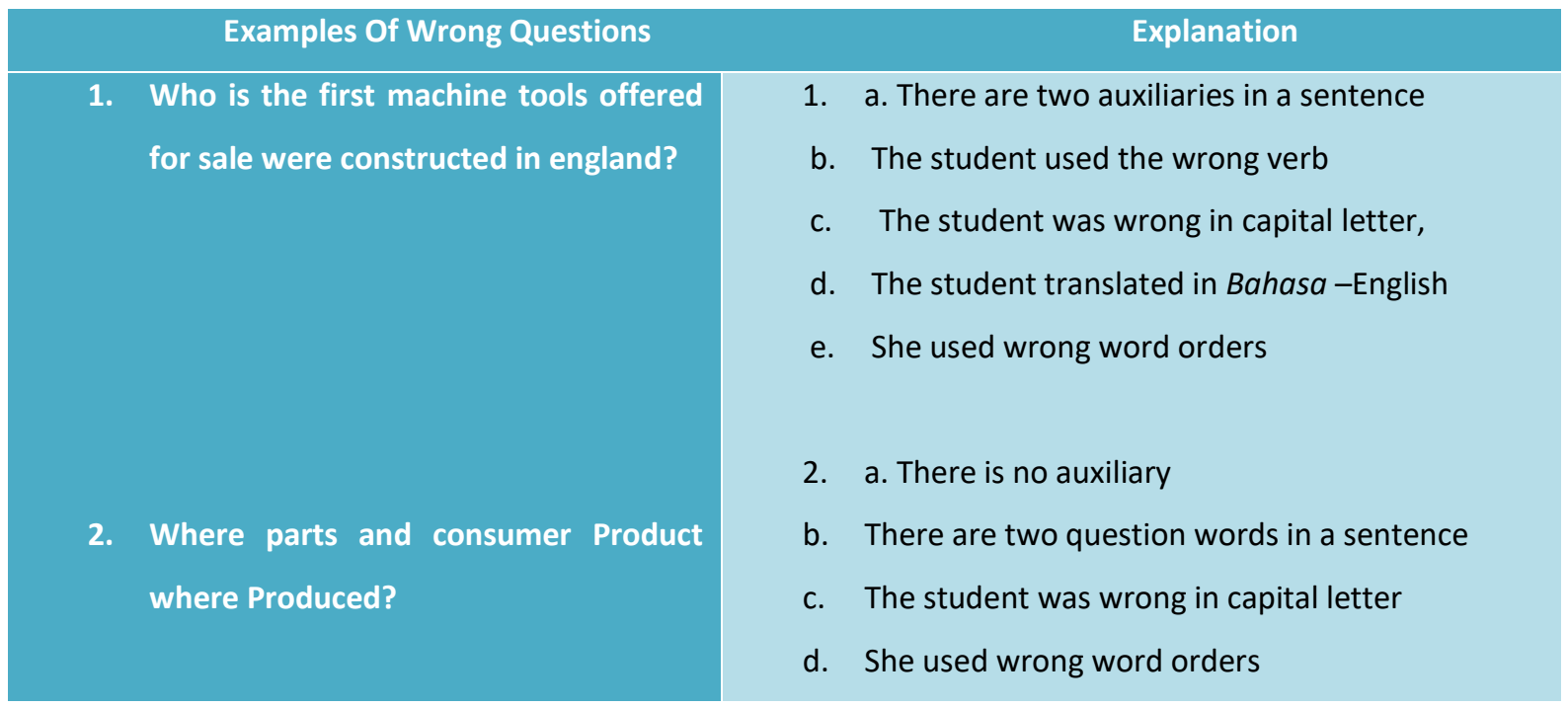


3. Who seller machine tools of the english first? e. There is no verb

3. a. There is no auxiliary

b. The student used the wrong (seller machine)

c. The student was wrong in capital letter

d. The student used the wrong verb

Table 1: Examples of several confusing questions

Those three questions made other students confused to understand the questions and it gave a bad impact that the students could not find the answer in the text. There were several reasons which made the students hard to understand the meaning of the question, such as no auxiliary, translate it into Bahasa to English without suitable grammatical, wrong word orders, etc. So, it made the students ask many times. There were many errors in the answers. They were still confused about how to arrange the sentences well. There are several examples as follow:

\begin{tabular}{|c|c|}
\hline Examples of Wrong Answers & Explanation \\
\hline $\begin{array}{l}\text { 1. What usability engine plant? } \\
\text { Machinery factory is afactory that } \\
\text { Produces Machines }\end{array}$ & $\begin{array}{l}\text { 1. There is no auxiliary in answer sentence } \\
\text { b. Wrong word order } \\
\text { c. No verb in answer sentence } \\
\text { d. error in space } \\
\text { c. capital letter and sign }\end{array}$ \\
\hline $\begin{array}{l}\text { 2. Why do you make use of tathe? } \\
\text { tidak tahu Karna Ini Pertanyaan } \\
\text { Mesin bubut bukan Mesin Pabrik }\end{array}$ & $\begin{array}{l}\text { 2. The question was unclear because the subject was } \\
\text { wrong and there were double verbs without a } \\
\text { conjunction. So it made another student cannot } \\
\text { answer the question. The student wrote if he could } \\
\text { not understand the meaning of the question }\end{array}$ \\
\hline $\begin{array}{l}\text { Found in countries as england, } \\
\text { france, Germany }\end{array}$ & $\begin{array}{l}\text { 3. This answer was not clear enough because there was } \\
\text { any auxiliary, the student was wrong in capital letters, } \\
\text { and this was an incomplete sentence. }\end{array}$ \\
\hline
\end{tabular}

Table 2: Examples of wrong answers

We can see from the examples, almost all of the errors were grammatical errors, like to be missing and incomplete or wrong verb. The errors were not only grammatical but also capital letters and word order. Capital errors and word order almost happened in all writing because the students did not understand well how to use a capital letter and arrange suitable word order. Example number 1, the student wrote a confusing question. He made a few errors 
like no auxiliary, no verb, and miss type. The answer given was also wrong but the reader could get the meaning of the writer although he made mistakes in auxiliary and in spacing.

Question number 2 was really hard to understand the meaning because the students put double verbs in a sentence but it is not a causative sentence. One of the verbs must be erased and nouns must be revised to make the reader catch the point of the question. The response told was in Bahasa and the response was that another student could not answer the question because his friend gave the wrong question, "ini pertanyaan mesin bubut bukan mesin pabrik". It showed that the student did not catch the meaning of the text. An incomplete sentence was found in answer number three. This sentence was not grammatically right but the reader could understand the meaning of the answer.

The last task given was that the students had to write a summary after answering the question. When they tried to find the answer to the questions given, they had to read and understand the content of the text. If they understand the meaning of the text, they can answer the question clearly. That is why, to know their understanding of the text content, they had to write a summary. Here is an example of the summary written by a mechanical engineering student.

factory Machine Created to meet the needs of Consumen and In the first half of the $19^{\text {th }}$ Century gradually the Wooden Machiner got replaced by metal machine Table 3: Example of the summary written

From the summary, we can conclude that the student did not understand the content of the text. He just got little information or text understanding. He also made many mistakes in his writing, such as using improper capital letters and punctuation. The sentences were not in proper grammatical sentences like any auxiliary and verb. They could not utilize the questions and answer to write the summary. The summary made the readers difficult to get the content of the sentence.

Few factors were making the students write many mistakes in their writing and it made them hard to understand the meaning of the text. At the beginning of the class, the lecturer did not explain to the students how to write a good sentence clearly. She just explained the outline of the materials. The students did not get motivation or brainstorming from her. When the students were doing their tasks, they looked so confused to do their tasks. Giving motivation or brainstorming to the students is very important to build their motivation and confidence. 
The lecturer surprised by the students' results. Then, she gave the same assignments to the students but she changed the way of teaching. She explained to the students how to write good sentences, how to create good questions, give brainstorming and motivation. After the lecturer explained clearly and gave some examples, the students looked enthusiastic to do the next tasks.

The lecturer divided the students into two groups; group A and group B. Group A and group B had different passages. Each student was given 40 minutes to read the text and write six questions based on the text. The lecturer always reminded the students to write clear sentences to make the reader understand. After 40 minutes, questions and text from group $A$ were given to group B and vice versa. The next tasks were that the students must answer the questions given and write a summary of the second text. The students could use questions and answer as the key to write a summary. Their time was 40 minutes. Many of the students could finish it before 40 minutes.

This situation was quite different from the first activity. In the second one, applying the asking question technique gave better improvement. There were only a few errors in question sentences, answer sentences, and summary. Their questions were easier to understand and it made the reader answer the question given. The students were able to write longer summary and they wrote in good sentences helped by the questions and answer. There are few examples of students' questions.

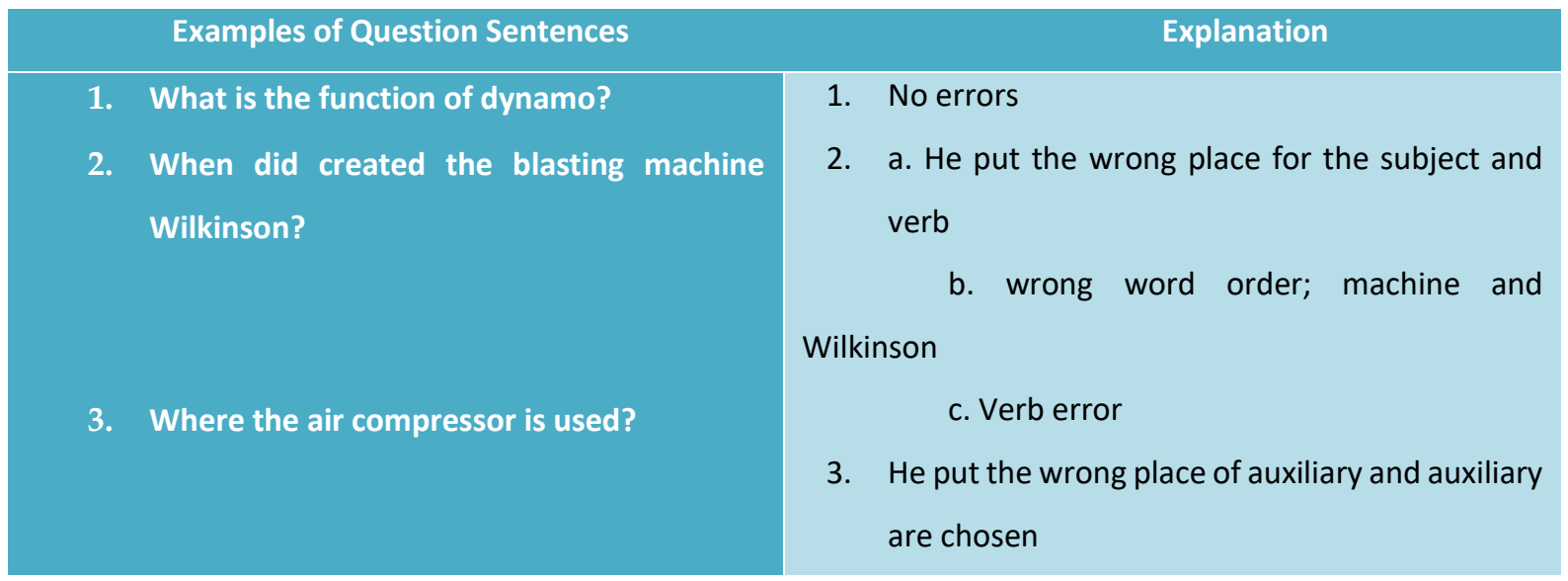

Table 4: Examples of question sentences

We can see the difference of students ' sentences before and after the teacher explained the materials and motivated the students. We can see from those three sentences. In the first example, the students did not make any mistakes. The second and the third sentences still had few mistakes but the reader was able to understand the meaning. The 
significant change has also happened in answer sentences. There were several examples of answer sentences.

\section{Examples}

1. When people start using air compressor to transmit energy?

People start using air compressor to transmit energy by 1800 .

2. Who is invented the blasting machine? He is Mr. Wilkinson.

3. Where is Viktor Popp create the first compressor?

Austrian engineer Viktor Popp created the first compressor plant in paris in 1888 , in just three years, Popp's 1500kw compressor plant grew to $18.000 \mathrm{kw}$.

\section{Explanation}

1. The student did not put auxiliary in this sentence and the answer sentence, the student used the wrong verb.

2. In both sentences, they used the wrong auxiliary

3. In the question sentence, there were two errors; use of auxiliary and verb. In the answer sentence, there were miss type and capital letter used.

Table 5: Examples of answer sentences

Errors in the use of auxiliary and verb often occur in students' writing. The students were still confused to use appropriate auxiliary and verb. Errors in punctuation and capital letter used were dismissing. Changing occurs not only in writing short sentences but also in paragraphs written in summary. The students were able to write several sentences and those sentences were easier to understand. This is one of the examples of students' summary.

The fact of the sun is possible to imagine that the sun is a big magnet, with a north pole and a south pole. The sun was discocery for about 100 years. In 1868-1938 Mr. George Ellery Hale is first astronot america to show that sunspots are regions on the solar surface. All the people can see of the sun used satelite and teleskop. The flow of electrons are metals (unlike is plasma) electrons aren't bound to the atoms and can move around freely. This way of generating electric current is based on a physical principal called elektromagnetic induction. this principle states that if a conductor (here the rotating disc) moves through a magnetic field. Today, most solar physicists believe that the solar dynamo is located either at the bottom of the convention zone. Thin region called the overshoot zone. The overshoot zone is located between the convention zone and the radioactive zone. 
The summary above has good improvement. There are only a few mistakes made by the student, like the use of the capital letter, phrase chosen, and word order. The grammar is also improved rapidly. This summary shows that the students have understood how to write good sentences.

The samples of the data show that the ways of lecturer's instruction and teaching are very influential to students' success in writing and understanding the text. It's like Toyoda said that the content and the question given by the students must have correlation and write clearly to get surprisingly answer and you could learn something new (Leech 2002). The first and second activities are quite different. In the first one, there were so many errors found in data samples because there was no engagement between the content and questions given and it also supported with grammatical errors. So, it would make others hard to answer the questions given. But it was quite different from the second one. There were only several errors found in the second activity because the students have understood the content and how to write the sentences well. It made other students easy to answer the questions and write the summary. The readers were easy to understand the meaning and content of their writing.

\section{Conclusion}

Asking a questioning technique can help the students to write the sentences well and understand the text. The students must read the passage given and write six questions using the WH-question mark (what, when, why, where, who, and how) questions. Then, others must answer the questions given (each student must read 2 passages) and write a summary. Explaining materials and giving brainstorming influences the success of this technique.

\section{Implications of Findings}

Although this research is conducted at the university, it is necessary for teachers, tutors, and parents to familiarize students or children with questions from the beginning six questions using the WH-question mark (what, when, why, where, who, and how) questions. This is to train you to ask critically later when you become older. Because actually, the basic question with WH question is, directing students to take philosophical views.

\section{Bibliography}

Brown, H. Douglas. 2000. Teaching By Principles: An Interactive Approach to Language Pedagogy. 2nd ed. London: longman. 
Leech, Beth L. 2002. "Asking Questions: Techniques for Semistructured Interviews." PS: Political Science \& Politics 35 (4): 665-68. https://doi.org/10.1017/S1049096502001129. Lopatovska, Irene, and Deanna Sessions. 2016. "Understanding Academic Reading in the Context of Information-Seeking." Library Review 65 (8/9): 502-18. https://doi.org/10.1108/LR-03-2016-0026.

Mikulecky, Beatrice S, and Linda C N - PE1128 .M555 2005 Jeffries. 2005. Reading Power: Reading for Pleasure, Comprehension Skills, Thinking Skills, Reading Faster. 3rd ed. White Plains, N.Y: Pearson Education.

Muslimah, Maziyyatul. 2018. “Is Students' Speaking Participation Related to Students' Personality and Gender?" ALSUNA: JOURNAL OF ARABIC AND ENGLISH LANGUAGE 1 (1): 1-16. https://doi.org/10.31538/alsuna.v1i1.30.

Rabaud, Caroline, Naushad Mamode Khan, and Smita Rampat. 2018. "Independent and Digital Reading among Undergraduates: The Case of the University of Mauritius." Journal of Applied Research in Higher Education 10 (3): 296-310. https://doi.org/10.1108/JARHE09-2017-0117.

Sulaiman, Masagus, and Harpiansi Harpiansi. 2018. "The Correlation Between Reading Habit and Students' Reading Comprehension Achievements." ALSUNA: JOURNAL OF ARABIC AND ENGLISH LANGUAGE 1 (2): 78-86. https://doi.org/10.31538/alsuna.v1i2.87.

Wardhani, Norita Prasetya. 2012. “Using Asking-Question Technique with Hello Magazine in Increasing Reading Descriptive Text to Eight Graders of SMP YPPI 2 Surabaya." Universitas Negeri Surabaya.

Wineland, Donna. 2016. "The Not-Reading Epidemic: Reflections of a Mid-Service English Teacher." English Teaching: Practice \& Critique 15 (2): 251-59. https://doi.org/10.1108/ETPC-07-2015-0054.

Woolley, Gary. 2011. Reading Comprehension. New York: Springer Science. 